scien do Zagreb International Review of Economics \& Business, Vol. 22, Special Conference Issue, pp. 83-94, 2019 (C) 2019 Faculty of Economics and Business, University of Zagreb and De Gruyter Open All rights reserved. Printed in Croatia ISSN 1331-5609; UDC: $33+65$

DOI: 10.2478/zireb-2019-0006 CONFERENCE PAPER

\title{
Organization in New Business Environment: a Franchisor's View
}

\author{
Matej Lahovnik* \\ Edith Bečić Steiner ***
}

Abstract: This paper investigates the basic risk and incentives relationship in franchising companies. The results of past research reflect volatile influence of risk and incentives. An in-depth analysis of this relationship was conducted using case study approach, including 12 international franchise firms of two types. Our study included retail and service franchising. Findings from this research confirm basic agency theory predictions. The risk-incentives relationship is negatively correlated in retail franchise companies, due to lower royalties in the sector. Service franchise companies do not follow the same concept, due to their adaptability of franchise system to local markets. We believe service franchise systems might be responsible for volatility. However, both types of companies nurture and develop strategies based on experience and intuition. Findings of the research offer important insights in understanding the nature of franchisor's risk perception, as the basic underlying mechanism to the risk and incentives relationship.

Keywords: franchising; risk; royalties; incentives

JEL Classification: M10, M16

\section{Introduction}

Franchising has been one of the most popular growth strategies in the last decade. We may expect further growth of this strategy in the near future. Risk and incentives have an interesting relationship when observed in franchising. For more than three decades researchers have been trying to understand the relationship between risk and incentives (Tebourbi, 2016). Some studies on this topic, applied agency theory (Ben-

\footnotetext{
" Matej Lahovnik is at Faculty of Economics, University of Ljubljana, Ljubljana, Slovenia.

${ }^{* * *}$ Edith Bečić Steiner is at FranAdria.
} 
dickson et al., 2016; Bosse, Phillips, 2016) view to analyse this relation and showing that the agency theory predictions regarding the negative relationship do not always hold. The original agency theory model proposes that risk-averse employees do not accept pay based on performance when the risk in environment rises. Consequently, the model predicts the incentives (performance based pay) are lower in more uncertain environments. Negative relation in the context of employer-employee relationship was confirmed by many studies mostly by analysing the context of executives and employees.

In franchising, the relationship between the risk and incentives shows inconsistent pattern. Several studies (Lafontaine and Slade 2002; Lafontaine, Roger, Arbor, 2005) point to the inverse relationship as an interesting phenomenon since the risk encourages the franchisee's choice for investment. Due to inconsistent results in past studies, we believe there is a gap of understanding the relationship between the risk and incentives in franchising.

Our emphasis is on examining the in-depth nature of risk and incentives in franchising. The key research question is how the franchisors relate to risk and incentives. Since risk and incentives according to agency theory have a negative relationship, we test whether the predicted negative relation between risk and incentives holds in the setting of twelve retail and service franchise firms. A purpose of our paper is to understand perspectives of risk and incentives attitudes in order to explain the inconsistency of past researches. According to Lafontaine and Slade $(2002,2007)$ incentives differ in franchise relationships due to industry sector of franchise companies. Therefore, our qualitative comparative case study includes 12 global franchise companies -6 retail and 6 service franchise companies.

To satisfy the triangulation and to secure construct validity the franchise consultants as another source of data are included in our research. All these franchise consultants have rich experiences - minimum of 30 years. They all created lots of different franchise system that are present for more than 20 years on the franchise global market. This paper has the following structure. We first provide a review of relevant studies of this topic in franchising and its research deficit. Following chapter describes the study methodology and reasons for using qualitative study in our case. Furthermore, we summarize results of the data analysis. Discussion of results brings us to final conclusion of the study's findings and implications.

\section{Literature Review Regarding Risk and Incentives in Franchising}

As suggested by Prendergast (2002) the empirical work that investigated negative trade-off between the risk and incentives has not shown a very much support of agency theory prediction. The results of past studies by taking different measure of 
incentives shows a rather inconsistent picture of the relation between risk and incentives (Altinay et al., 2014, Alon 2012).

Some authors re-emphasize a positive relation between risk and incentives (Lafontaine, Roger, Arbor, 2005; Lafontaine, Slade 2007). The past researches on retailing conclude that different indicators determine franchise contract. The contract terms in form of royalty are reflected with franchisor's importance of effort, which lowers the franchisee's effort. Factors such as risk and agent's effort tend to increase the franchisee's effort (Wimmer, Garen, 1997; Lafontaine, Roger, Arbor, 2005; Lafontaine and Slade, 2007).

Vazquez's results (2005) confirm the positive relations between the risk and royalties. A sharing parameter in terms of franchisee's effort was accentuated (Kosova, Lafontaine, 2010). Higher franchisee's effort results in lower royalties. Authors imply new explorations are needed in order to address the share parameter within business relationships. New researches executed in Japan based on Lafontaine's model proved negative influence of outlet risk on royalties (Maruyama, Yamashita, 2010; 2012). They find out that franchisors with smaller margin rates are forced to charge higher royalties as the service franchise companies. We outline latest studies using risk measurement by focusing on many other parameters and not just relation to incentives including margins as one form of incentives related to market size or franchise industry type. We need to embrace new approaches of analysis with integration of "new paradigms" (Dant 2008; Denzin and Lincoln 2011).

\section{Research Methodology}

Our study focuses on relationship between risk and incentives from franchisor's perspective, where the focus is on exploratory in-depth analysis of relationship under study. We undertook a multiple case study approach in order to explore different cases with tendency of comparison. We decided to choose two types of franchise companies - retail franchise companies and service franchise companies. Our results are derived from 12 case studies of global franchise companies and 4 franchise consultants. Therefore, our study is not limited to a country or territory and it is the first global study executed in terms of risk and incentive issues. Within each case study we contacted the franchise management in the company or franchise consultants directly. Franchise companies were contacted by phone. Introduction to the company was made either by email, personally or by phone (30 minutes introduction) followed by interview with semi-structured interview guideline (duration approximately 55 minutes). We short-listed 20 global franchise companies with presence at EU market and criteria of minimum 10 years of franchise experience including minimum 150 franchise units. 12 companies accepted to participate - 6 retail and 6 services. 
Eight franchise consultants were shortlisted based on minimum 30 years of franchise experience from UK, U.S and Australia. Four of them accepted the participation. The interviews with franchise consultants served to fulfil the triangulation conditions with duration of approximately 70 minutes as suggested by some scholars (Creswell 2013). Franchise companies were randomly contacted at franchise exhibitions or different franchise events all over the world. Our target respondents were top managers or owners.

The semi-structured interview guideline was set up based on independent variable as parameters of environmental uncertainty, institutional uncertainty, economic uncertainty and cultural uncertainty. Incentives as dependent variable were measured with the level of royalties. The interview guideline included 22 questions, 12 questions were based on variables measured in the model. In order to achieve the comparison between the variables we stated questions about 3 types of uncertainties with their relation as "the most important, medium important and the least important".

Another group of interviewees was selected to gain a supplement to other methods in order to give a correct position including the maximization of our understanding of the study (Clifford, French, and Valentine, 2010). Questions were stated in a general form with purpose to gain their working experiences in 30 years but always referred to determined variables (environmental uncertainty, incentives). We encouraged open questions in order to achieve in-depth knowledge how certain variable effected company's success or failure in international franchising. The questions about certain construct were stated as an inquiry into their general experience with environmental uncertainty in terms of economic, legal and cultural. Consequently, we encouraged them to explain their valuable insight stating effects toward avoiding the failures and importance of steps for franchise companies to achieve success.

Using franchise consultant's overview for the first time in qualitative studies we examine their experiences through franchisor's mistakes. In this way we formulated different guidelines for determinants in franchise contracts. The recorder semi-structured interviews were executed face to face or by using Online Tools such as Skype.

Franchise consultants represent a very important group in our research. Different resources in collecting the data put the internal validity on a higher level. We even managed to get collaboration of franchise consultant coming from different continents. This means the results revealed us also different perspectives in a global matter. Each franchise consultant has more than 30 years of franchise experience. Our interview guide was adapted for franchise consultants, but still following the semi-structured interview guideline for franchise companies. All these interviews were longer than 45 minutes and the discussion was very active with lots of additional information based on describing the mistakes made by franchisors.

All 16 interviews were transcribed and analyzed with pattern matching method of analyzing texts. We assured strict confidentiality to all participants and each was giv- 
en a code name in order to ease the analysis. Each of the interviewees was informed about the purpose of the research and how the data will be used. The process revealed common and contradicting themes. Franchise overview of the incentives was collected in order to put also royalty together with different other forms of franchise fees such as IT or marketing fee.

\section{Results}

\section{Evaluation of the risk as environmental uncertainty}

Our study reveals that it is expected of a franchisee in retail franchise to deal with the risk of the local market. When franchise retail companies were asked about the risk at the franchisee's market, they replied the risk is always being taken by the franchisee. Before signing the contract all companies have done a thorough research of franchisee's local market to find out if the local market accepts the business model as well as if the figures provide a feasible income. Another issue retail franchisor outline is the supply and logistics that follow their expansion to another market. In this way, their industry has to be followed with an additional support. If these activities were not followed by franchisor, the franchisee would be disabled to open the franchise unit.

Table 1 describes evaluation of uncertainty by retail franchisors. Most of them describe the cultural uncertainty or economic uncertainty as important and challenging. Only tea selling company from Austria sees no issue in it. Some companies put cultural uncertainty on the first place and some other economic uncertainty as the most important one. Cultural issues were addressed in order to discover if the franchise business matches the local society in terms of habits or hobbies. These issues were mostly solved by the franchisee. In particular they outlined the cultural differences as they cannot be solved when it comes to their products. The Austrian lingerie company and German bakery company outlined the adaptability of the product as crucial in their business. Economic uncertainty demanded cooperative work in order to find out if the local market suits the financial needs that the franchisor's business demands in order to assure profit for the franchisee. All companies placed the institutional risk as the least important. 
Table 1: Evaluation of uncertainty by the retail franchise companies

\begin{tabular}{|c|c|c|c|}
\hline $\begin{array}{l}\text { Franchise } \\
\text { company }\end{array}$ & Industry & Relation to risk & Evaluation of environmental uncertainty \\
\hline $\mathbf{R 1}$ & $\begin{array}{l}\text { Tea } \\
\text { selling }\end{array}$ & $\begin{array}{l}\text { "We check them as emerging mar- } \\
\text { kets and we offer then normally li- } \\
\text { censing or master franchising. We } \\
\text { do not really check out the market } \\
\text { so much as we have the franchisee } \\
\text { who takes over the responsibility." }\end{array}$ & $\begin{array}{l}\text { »A feasibility study is done together with our } \\
\text { franchise candidate. We would evaluate together } \\
\text { if the market was appropriate for us. The culture } \\
\text { does not play important role and neither do legal } \\
\text { issues. Therefore, it is up to franchisee, how he } \\
\text { will succeed « }\end{array}$ \\
\hline $\mathbf{R 2}$ & Clothing & $\begin{array}{l}\text { "We do not execute any risk assess- } \\
\text { ments. If the franchisee liked the } \\
\text { franchise, we would sell the license. } \\
\text { If the market was too risky in terms } \\
\text { of getting our payment for clothing, } \\
\text { we would sell a license or we would } \\
\text { just execute the export to the market } \\
\text { with demanding advance payment." }\end{array}$ & $\begin{array}{l}\text { "We try to evaluate the cultural fashion styles, } \\
\text { which is also in our case important not so much } \\
\text { in Europe, but also in China, Russia or Middle } \\
\text { East." }\end{array}$ \\
\hline R3 & $\begin{array}{l}\text { Selling } \\
\text { cosmetic }\end{array}$ & $\begin{array}{l}\text { "We do not really check out the } \\
\text { market so much as we have the fran- } \\
\text { chisee who takes over the responsi- } \\
\text { bility." }\end{array}$ & $\begin{array}{l}\text { "Yes, legal risk is important. Also the cultural } \\
\text { risk is being researched. Usually, we pay atten- } \\
\text { tion to economic risk. Although, our products can } \\
\text { be sold even in the markets with lower purchasing } \\
\text { power." }\end{array}$ \\
\hline $\mathbf{R 4}$ & Lingerie & $\begin{array}{l}\text { "We check the competitors, frequen- } \\
\text { cy of the potential buyers, rent level, } \\
\text { incomes." }\end{array}$ & $\begin{array}{l}\text { "Usually, the institutional issues are not a prob- } \\
\text { lem. We could deal with some issues just when it } \\
\text { comes to different body measures in terms of oth- } \\
\text { er nations such as Chinese or Japanese market." } \\
\text { "We see no legal issues and the most important } \\
\text { for us is the economic uncertainty." }\end{array}$ \\
\hline $\mathbf{R 5}$ & Bakery & $\begin{array}{l}\text { »We do not have risk - as we deal } \\
\text { with one person." }\end{array}$ & $\begin{array}{l}\text { "If someone from Albania came to us to buy our } \\
\text { franchise, we would believe that there are too } \\
\text { many cultural issues and this would not be ac- } \\
\text { ceptable for our system." } \\
\text { "Cultural habits of eating play a significant role } \\
\text { in making a decision, if we can be successful with } \\
\text { our bakery." }\end{array}$ \\
\hline R6 & $\begin{array}{l}\text { Bird } \\
\text { Feeding }\end{array}$ & $\begin{array}{l}\text { "We have to do as much as possible } \\
\text { to predict the problems our franchi- } \\
\text { see might have. Of course it is the } \\
\text { franchisee, who takes the whole } \\
\text { risk." }\end{array}$ & $\begin{array}{l}\text { "The most challenging is predicting their turn- } \\
\text { over. We start with the most important one. This } \\
\text { is usually the GDP or income level. As we are a } \\
\text { very unique system, we specifically check first the } \\
\text { bird feeding habit at the market." }\end{array}$ \\
\hline
\end{tabular}

From the viewpoint of retail franchisors the biggest challenge in international franchising is the process of finding out how their business could be adapted to succeed in the local market. All service franchisors claim how their system is due to services adaptable. It just depends mostly on economic issues how these services are being valued and also on the franchisee's profile. Most of the service companies perceive legal uncertainty as the least important for their franchise system. It is considered as a protection of their know-how, but not of major concern. Most of 
the companies explained that they have a good legal attorney to take care of their legal uncertainties. Economic and cultural uncertainties are being considered to be evaluated during the recruitment process together with franchisees. Both of these types of risk have feasible opportunities in the local market. Therefore, this enables service companies to perceive the risk in the franchisee's local market at a lower level.

Franchise service companies indicated cultural uncertainty as one of the most important concerns (see Table 2). The replies given from service franchise companies outline how the risk is the franchisee's responsibility. The franchisors help their franchisees to find out the feasibility of the franchise business. They argue that environmental uncertainty when expanding to distant markets risk does not present such a big issue. They tend to use very extended and thorough plans of trainings called as modules or phases. During the trainings, they solve the challenges they have regarding adaptability of the services. In general, they plan their transfer of specific knowledge in a longer period between 9 and 12 months. They all keep their knowhow in on-line intranet form. Therefore the education process can be assured in 24/7 form. The more distant the market is, the longer the period of trainings in order to overcome all the differences.

All service companies agree that economic uncertainty plays the most important role in setting up a new franchise. When companies were asked about institutional and cultural differences, most of them stated the cultural difference is more important than the institutional due to their strong legal departments or lawyers. They are able to adapt their franchise contract according to different law or legal differences applied to host market.

To summarize, retail franchise companies are aware of higher level of environmental uncertainty. It disables them to sell franchise license in order to achieve trust, appropriate support and supply. Another option for them is to execute simple wholesale export activity which means no franchise relationship. All retail franchise companies exposed their problem of franchising in adaptation of their business system in the distant markets. Despite careful decision-making when it comes to riskier markets, they outlined that in the end it is the franchisee that carries the whole risk. Service companies are mostly worried about the cultural uncertainty. They don't perceive significant problems to overcome the economic or institutional differences. Mostly, they adapt the business franchise model to local market. Their biggest concern is mostly the selections of the franchisee as the suitable person who takes care of the investment. 
Table 2: Evaluation of uncertainty by the service franchise companies

\begin{tabular}{|c|c|c|c|}
\hline $\begin{array}{l}\text { Franchise } \\
\text { company }\end{array}$ & Industry & Relation to risk & $\begin{array}{c}\text { Evaluation of environmental } \\
\text { uncertainty }\end{array}$ \\
\hline S1 & Headhunting & $\begin{array}{l}\text { "Our richest market at the moment is } \\
\text { taken care with someone locally so we } \\
\text { do not have any problems regarding } \\
\text { cultural issues." }\end{array}$ & $\begin{array}{l}\text { "It is in some areas absolutely fine. In } \\
\text { Europe we can sue someone. In many EU } \\
\text { countries we have a good chance to actu- } \\
\text { ally win the case. We are very concerned } \\
\text { about the USA. Big areas are the emerg- } \\
\text { ing markers. China, Africa, Middle East. } \\
\text { Do we have interest in Africa? Maybe, } \\
\text { south Africa... It is always going down to } \\
\text { Commonwealth countries due to legisla- } \\
\text { tion as it is very similar." }\end{array}$ \\
\hline S2 & $\begin{array}{l}\text { Business } \\
\text { Consultancy }\end{array}$ & $\begin{array}{l}\text { "They need to determine if this is the } \\
\text { risk they want to be exposed to. How- } \\
\text { ever, we have found that whenever the } \\
\text { franchisee follows the protocols in our } \\
\text { system, they do it wonderful." }\end{array}$ & $\begin{array}{l}\text { "First of all, we look at country's eco- } \\
\text { nomic system and then we pay attention } \\
\text { on the government and last but not least } \\
\text { we consider the political system. We try to } \\
\text { evaluate the characteristics of the bank- } \\
\text { ing system. Based upon these risks we } \\
\text { would negotiate with our franchisee." }\end{array}$ \\
\hline S3 & $\begin{array}{l}\text { Business } \\
\text { Coaching }\end{array}$ & $\begin{array}{l}\text { "We have learned from our past mis- } \\
\text { takes and we have talked with many } \\
\text { people about the research of a single } \\
\text { market how to approach to unknown } \\
\text { market in a best way possible. How } \\
\text { to overcome huge problems in these } \\
\text { phases." }\end{array}$ & $\begin{array}{l}\text { "The most important factors are: GDP, } \\
\text { existing franchisees or similar franchises } \\
\text { developed. We check if there are any oth- } \\
\text { er coaching businesses or other similar } \\
\text { business companies. This could be rather } \\
\text { a huge problem for us." }\end{array}$ \\
\hline S4 & Networking & $\begin{array}{l}\text { "The biggest challenge: different men- } \\
\text { tality - everybody starts with it. Every- } \\
\text { body including US companies have this } \\
\text { kind of problems. It is harder to sell a } \\
\text { franchise outside of L.A. The closest } \\
\text { franchise unit is the more likely will } \\
\text { be successful". The biggest hurdle is } \\
\text { getting passed this claim of being dif- } \\
\text { ferent." }\end{array}$ & $\begin{array}{l}\text { The same service franchise company with } \\
\text { more than } 400 \text { franchise units all over the } \\
\text { world in networking industry replied: } \\
\text { "Economic uncertainty is not a problem } \\
\text { and institutional just in terms offranchise } \\
\text { laws... However, it is possible to over- } \\
\text { come these problems. We have the biggest } \\
\text { problem regarding cultural terms." }\end{array}$ \\
\hline S5 & $\begin{array}{l}\text { Computer } \\
\text { education }\end{array}$ & $\begin{array}{l}\text { "We do this to make sure that the econo- } \\
\text { my is still going. The calculations of risk } \\
\text { had been executed before the contract } \\
\text { was signed." }\end{array}$ & $\begin{array}{l}\text { "So we turn our attention to economic } \\
\text { uncertainty and not so much to legal, } \\
\text { institutional or cultural. The franchisee } \\
\text { must only take care that we are not re- } \\
\text { leasing the info". }\end{array}$ \\
\hline S5 & $\begin{array}{l}\text { Printing } \\
\text { services }\end{array}$ & $\begin{array}{l}\text { "The real risk comes from people who } \\
\text { cannot follow the system. There is a } \\
\text { risk that a franchisee has not done its } \\
\text { job with due diligence and overviewed } \\
\text { the whole risk situations in his business } \\
\text { plan. There is a certain risk if do not } \\
\text { have the independent experience." }\end{array}$ & $\begin{array}{l}\text { "In the past we avoided areas where the } \\
\text { most important risks are legal... Let's } \\
\text { take China for example. In our industry } \\
\text { there are many companies which come } \\
\text { with their own solutions and they will } \\
\text { copy the cartridges. We do not have any } \\
\text { legal rights due to the legal system. Sim- } \\
\text { ilar applies to the trade marks in India } \\
\text { and China. Therefore potential franchi- } \\
\text { sees can't be very successful.". }\end{array}$ \\
\hline
\end{tabular}




\section{Evaluation of the incentives}

We found out a very high difference in royalty levels between the retail and service franchise chains. On one hand the bakery company from Germany charges the highest one. On the other hand an Austrian company with underwear clothing charges none. They are both retail companies. Printing service franchise company form US set the minimum royalty with $6 \%$. We found out that the lowest royalty in services is the highest in retail companies. We have two companies with $15 \%$ of royalty and the highest is the $30 \%$ charged by Australian franchise company for business coaching. The average royalty in service franchise companies is 3-times higher than in retail companies. Royalty levels clearly show how retail and service companies differently structure the monthly royalty payments.

We may argue that franchisors are ready to lower the royalty rates. The franchisors claim they are even prepared to give up royalties for a certain period of time to provide more incentives to franchisees. Both types of franchise companies (see Table 3) provided these kinds of incentives to franchisees in case the risk would rise at the franchisee's local market. Our study suggests that franchisors are ready to adapt their royalty level for a certain period of time, which gives additional incentives to franchisees.

Table 3: Incentives by retail and services franchise companies

\begin{tabular}{|c|c|c|c|}
\hline $\begin{array}{l}\text { Retail } \\
\text { companies }\end{array}$ & $\begin{array}{l}\text { Change of royalties and additional } \\
\text { incentives for franchisors }\end{array}$ & $\begin{array}{c}\text { Service } \\
\text { companies }\end{array}$ & $\begin{array}{l}\text { Change of royalties and } \\
\text { additional incentives for } \\
\text { franchisors }\end{array}$ \\
\hline $\begin{array}{c}\text { R1 } \\
\text { Tea selling }\end{array}$ & $\begin{array}{l}\text { "We really want to help them to realise their } \\
\text { dreams. Since our system is pretty much or- } \\
\text { ganised and prepared for analysing the host } \\
\text { market, we offer them any help they need } \\
\text { and we do not charge them. We believe they } \\
\text { deserve and need our help at the beginning } \\
\text { therefore they've stepped into a franchise } \\
\text { system." }\end{array}$ & $\begin{array}{c}\text { S5 } \\
\text { Computer } \\
\text { Education }\end{array}$ & $\begin{array}{l}\text { "Well, these things also happen } \\
\text { and if we really see and find out } \\
\text { certain things are not working for a } \\
\text { franchisee, we'll agree to lower the } \\
\text { royalty level for a certain period of } \\
\text { time. In this way we help them ad- } \\
\text { ditionally on local market to make } \\
\text { their business recover." }\end{array}$ \\
\hline $\begin{array}{c}\text { R2 } \\
\text { Clothing }\end{array}$ & $\begin{array}{l}\text { "We do a lot of support. Also not standard- } \\
\text { ized support. When franchisee needs support } \\
\text { or advice they turn to us. We consult them ac- } \\
\text { cording to how we do business in our compa- } \\
\text { ny units. Just our experience that we transfer } \\
\text { to them is valuable for them." }\end{array}$ & $\begin{array}{c}\text { S3 } \\
\text { Business } \\
\text { Coaching }\end{array}$ & $\begin{array}{l}\text { »We would give them extra coach- } \\
\text { ing, review of their marketing plans. } \\
\text { Our CEO will talk to them to see } \\
\text { what works for them and what does } \\
\text { not work. We certainly adapt to } \\
\text { their markets with their ideas." }\end{array}$ \\
\hline $\begin{array}{c}\text { R3 } \\
\text { Selling } \\
\text { cosmetics }\end{array}$ & $\begin{array}{l}\text { We are in particular paying attention at the } \\
\text { beginning of our relationship. If the local } \\
\text { market has been shown to have some partic- } \\
\text { ular issues we did not succeed to predict in } \\
\text { our recruitment phase. We help our franchi- } \\
\text { see with additional support by being present } \\
\text { in the unit more often locally. We even lower } \\
\text { or not charge them the royalty for a certain } \\
\text { period of time." }\end{array}$ & $\begin{array}{c}\text { S6 } \\
\text { Printing }\end{array}$ & $\begin{array}{l}\text { "We do not charge our franchisee } \\
\text { additionally if we help him or her } \\
\text { to find out if our system is at their } \\
\text { market scalable and profitable. We } \\
\text { really want to make sure at the be- } \\
\text { ginning of our relationship if the } \\
\text { franchise system will work and if it } \\
\text { is profitable." }\end{array}$ \\
\hline
\end{tabular}


Our comparative case analysis includes also international franchise consultants as a third party. Their replies explain how franchisors perceive risk and areas where franchisors often make mistakes. Mostly they refer to mistakes made in international franchising. Franchise consultants do not consider that the institutional uncertainty has a major role in influencing the royalties. After economic uncertainties the cultural differences were mentioned as crucial also. The cultural issue revealed a bigger importance in comparison to institutional challenges. Additionally, localization adaptability was mentioned with mistakes by global companies like McDonalds or Starbucks. Mistakes were in an interview described when these companies were entering the territories like India and Australia with a company-owned unit (subsidiary). No localization was made to local market uncertainties. All franchise consultants suggest that franchisors learn in their process of franchise experiences by not repeating same mistake twice. The franchise consultants additionally accentuated that care and trust play an important role.

\section{Discussion}

The results collected from retail and service company imply the importance of franchisor's effort which was also proposed by Wimmer and Garen (1997) and Vazquez (2005). Although, Lafontaine and Slade (2002) in their study suggest that franchisor's effort in terms of asset specificity should not be seen as an important role in franchising. We believe retail and service franchise companies do have some crucial differences in terms of intangible assets. This was implied by Maruyama and Yamashita (2012) despite their opposite conclusion that royalties are related to maintain input sales revenues. They both conclude that franchisor's and franchisee's efforts are important which our qualitative research confirms.

We can tentatively conclude service franchise companies have reasons to charge higher royalties with an assumption their effort shows a greater value. This was confirmed also by Maruyama and Yamashita (2012). Retail franchise companies evaluate risk on a higher level in comparison to services. This indicates retail franchise systems perceive risk higher due to selling products being unable to adapt to cultural differences. Retail companies set lower royalties rates and offer higher incentives to their franchisees. On the other hand, retail companies charge franchisees with extra margins on selling their products. According to our data, most of the retail companies charge margins from $50-150$ percent. Service franchise systems manage the risk with adaptability of their franchise system and they charge higher royalties. This type of companies does not confirm the predictions of the agency theory. The conclusion about retail companies and their margins should be used as a further indicator in determining the relations between the risk and incentives in franchising. 
Furthermore, the study appointed how franchisor's sense of risk leads to mistakes by not evaluating the risk in the local market. Franchisor's effort in developing trust with its CEO and the franchise support management team means a certain value to franchisee. The franchise consultants argue that leaders with their leadership style play an important role by gaining the franchisees effort and loyalty on their side. They outline franchise companies do not relate to individual needs of franchisees. Franchise companies very often provide framework of their support services not applied to cultural differences. Due to this reason, franchisors do not outline the risk-sharing in their franchise relationship. They admit it is up to their franchisee to face the risk. On the other side, franchisors execute their effort and franchisee applies their business model to local market.

\section{Conclusion}

The franchise companies in our study indicate complexity of franchise industry. Service companies outline that feasibility of their business eliminates the risk at the local market. Retail companies determine alternatives by not using franchising business model. It seems risk as a determinant of incentives does not apply to agency theory. Franchisors from our study understand that it is the franchisee that takes over the whole responsibility.

We found out that service companies have higher royalties which denies the agency theory predictions. On the other hand retail companies charge lower royalties. We believe incentives cannot be measured explicitly only by royalties. Margins should be included as well as other franchisor's incentives. The franchise firms are faced with paradigmatic change, resulting from evolution of franchise business models.

The results of this research clearly indicate that established agency theory approach has to be modified to address the new paradigm shift in basic operation of industry. Our research also provides some insights to the new potential franchisees, or franchise system owners. Better understanding of franchising leads small business owners to reconsider franchising as a business option. Complexity of franchise system demands higher level of control which creates again higher costs resulting in higher incentives.

Our research indicates franchisor's effort in terms of adaptability becomes a necessity in order for franchise unit to be feasible in the local markets. This factor is a necessity for successful international expansion. Furthermore, more experienced franchisors tend to take time and evaluate the local franchisee's markets. Experienced franchise companies actively develop strategies based on experience and intuition. We propose the influence of control in franchising with trust and care, to be investigated in further research. New forms of future research could reveal us further issues being present in relationship between the risk and incentives in franchising. 


\section{REFERENCES}

Alon, I. (2012). Global Franchising Operations Management: Cases in International and Emerging Markets Operations. New Jersey: FT Press.

Alon, I., McKee, D.L. (1999). The Internationalization of Professional Business Service Franchises. The Journal of Consumer Marketing, 16(1), 74-85.

Altinay, L., Brookes, M., Yeung, R., Aktas, G. (2014). Franchisees' perceptions of relationship development in franchise partnerships. Journal of Services Marketing, 28(6), 509-519.

Bendickson, J., Muldoon, J., Liguori, E., \& Davis, P. E. (2016). Agency theory: the times, they are changing. Management Decision, 54(1), 174-193.

Bernard, H. Russell (2011). Research Methods in Anthropology: Qualitative and Quantitative Approaches. Rowman Altamira.

Bosse, D. A., \& Phillips, R. A. (2016). Agency theory and bounded self-interest. Academy of Management Review, 4l(2), 276-279.

Clifford, N., French S., and Valentine G. (2010). Key Methods in Geography. Sage.

Creswell, J.W. (2013). Qualitative Inquiry and Research Design: Choosing among Five Approaches. Sage.

Dant, R.P. (2008). A Futuristic Research Agenda for the Field of Franchising. Journal of Small Business Management, 46(1), 91-98.

Denzin, N.K., Lincoln, S.Y. (2011). The SAGE Handbook of Qualitative Research. Sage.

Doherty, M.A., Chen, X., \& Alexander, N. (2014). The franchise relationship in China: agency and institutional theory perspectives. European Journal of Marketing, 48(9/10), 1664-1689.

Kosova, R., Lafontaine F. (2010). Survival and Growth in Retail and Service Industries: Evidence from Franchised Chains. Journal of Industrial Economics, 58(2), 542-78.

Lafontaine, F., Roger D.B., Arbor A. (2005). The Economics of Franchising. Cambridge: Cambridge University Press.

Lafontaine, F., Slade. M. (2007). Vertical Integration and Firm Boundaries: The Evidence. Journal of Economic Literature, 45(3), 629-685.

Maruyama, M., Yamashita, Y. (2012). Franchise Fees and Royalties: Theory and Empirical Results. Review of Industrial Organization, 40(3), 167-189.

Maruyama, M., Yamashita, Y. (2010). The Logic of Franchise Contracts: Empirical Results of Japan. Japan and the World Economy, 22(3), 183-192.

Prendergast, C. (2002). The Tenuous Trade-Off between Risk and Incentives. Journal of Political Economy, 110(5), 1071-1102.

Tebourbi, I. (2016). Trade-off between risk and incentives: Evidence from New- and Old- Economy Firms. Journal of Corporate Accounting \& Finance, 27(2), 53-71.

Vazquez, L. (2005). Up-front franchise fees and ongoing variable payments as substitutes: An agency perspective. Review of Industrial Organization, 26(4), 445-460.

Wimmer, B.S., Garen, J.E. (1997). Moral Hazard, Asset Specificity, Implicit Bonding, and Compensation: The Case of Franchising. Economic Inquiry, 35 (3): 544-54. 